\title{
Phenotypic variation in fruit and seed morphology of Adansonia digitata L (Baobab) in five selected wild populations in Malawi
}

\author{
C.R.Y Munthali ${ }^{1,4}$ P.W Chirwa ${ }^{2}$ and F.K. Akinnifesi ${ }^{3}$ \\ ${ }^{1}$ Mzuzu University, Private Bag 1, Luwinga, Mzuzu, Malawi. \\ ${ }^{2}$ Pretoria University, Lynwood Road, Hatfield, Pretoria, 0002, South Africa \\ ${ }^{3}$ World Agroforestry Centre (ICRAF), Southern Africa Regional Programme, \\ Chitedze Agricultural Research Station, P.O. Box 30798, Lilongwe 3, Malawi. \\ ${ }^{4}$ Stellenbosch University, Department of Forest \& Wood Science, Stellenbosch, South Africa
}

\begin{abstract}
Adansonia digitata L (Baobab) is widely distributed throughout Sub-Saharan Africa stretching from Senegal to Sudan, and from Ethiopia to Natal. Information of phenotypic and genetic variation is a prerequisite for the domestication and improvement of baobab fruits from the wild. A study was done to determine within and between provenance variability in fruit and seed characteristics of five populations selected from four silvicultural zones and assess whether morphometric traits could delineate populations from different zones into land races. Fruits were characterized from 55 trees representing a wide geographical range. Six fruit traits and three individual seed traits were assessed. Results showed highly significant differences $(\mathrm{P} \leq 0.001)$ in fruit, pulp, and seed weight, fruit length and width, number of seed, individual seed weight, seed length and width within and between populations. Mean fruit weight ranged from $125.8 \pm 3.25 \mathrm{~g}$ to $162.9 \pm 3.25 \mathrm{~g}$, seed weight ranged from $38.6 \pm 2.5 \mathrm{~g}$ to $66 \pm 2.01 \mathrm{~g}$ and pulp weight ranged from $28.7 \pm 1.33 \mathrm{~g}$ to $41.4 \pm 1.33 \mathrm{~g}$. Single seed weight showed pronounced evidence of divergence of populations into ecotypes. The rich diversity found between and within populations is important for domestication purposes and tree improvement through selection and breeding. All populations could be used for seed source but distribution should be consciously done recognizing existence of races.
\end{abstract}

Keywords: Ecotype, Domestication, Miombo, Diversity

\section{Introduction}

Adansonia digitata L (baobab) belongs to the family Bombacacea (Wickens 1982) and the genus Adansonia (Moiselet 1998). Adansonia is a member of the tribe Adansonieae, or Bombaceae (Sidibe and Williams 2002). Generally in Africa the species is indigenous in drier areas found in West Africa, Sudan, Angola, East Africa, Southern Africa up to Transvaal covering about 26 countries (Sidibe and Williams 2002; Wickens 1982). The importance of baobab to human livelihood is reviewed by several authors such as Gruenwald and Galiza (2005), Kalinganire et al (2008), Teklehaimanot et al. (2008), FAO (1982), Sidibe and Williams (2002) and ICUC 
(2002). In addition, baobab is currently a crop of high economic value internationally (De Smedt et al. 2011; Gruenwald and Galiza 2005). Baobab oil, extracted from the seed, is used in the cosmetics industry and is also sold internationally (Gruenwald and Galiza 2005). Baobab fruit pulp has been approved for sale in the EU (2008/575/EC) and USA (GRAS Notice No. GRN 000273) (De Smedt et al. 2011). With a wide range of geographical distribution, certain plant characteristics represent morphotypes (Sidibe and Williams 2002). Zobel and Tarbert (1984) have attributed phenotypic variations in forest trees to three factors: the differing environments in which the trees are growing, the genetic differences among trees and interaction between the tree genotypes and environments where they grow. Across geographical range of baobab, the major phenotypic variation reported include leaf taste, size, form and colour of fruits, seed colour, pulp taste and colour, bark colour, height and width of trees (Sidibe and Williams 2002; Assogbadjo et al. 2006) and fruit traits (Smedt et al. 2011). Presently, domestication of baobab in southern Africa has begun with selection of clonal propagation, especially in Zambia and Malawi (Akinnifesi et al. 2008b).

With domestication, phenotypic and genetic aspects should be embedded in baobab domestication process to confer tree populations the ability to keep an appropriate level of genetic diversity to maintain short-term viability and long-term evolutionary potential (Buiteveld et al. 2007). Forest management may affect the genetic resources through drift, mating system, fertility and viability selection, and migration (Buiteveld et al. 2007). Natural selection has resulted in formation of geographical races (ecotypes) in tree species (Chapman and Reiss 2000) which are in most cases genetically controlled (Zobel and Tarbert 1984) and should be considered in tree domestication, conservation and improvement strategies. Studying phenotypic and genetic variation in heterogeneous environment is key to understanding factors that shape the population structure on which tree domestication, conservation, management and improvement strategies can be modeled (Bizoux and Mahy 2007). Katsvanga et al. (2007) have also reported high variability in fruit traits among sites largely attributed to climatic, edaphic, genetic, and cultural factors. The extent to which individuals develop within the species is also a function of the mechanism of seed dispersal (Chung et al. 2002). In addition, management regimes within a given environment may also cause morphological variation especially for traits targeted by artificial selection (Carmona and Casas 2005). Patterns of genetic structuring among 
populations may be continuous, as in isolation -by-distance models of gene flow or discontinuous as in stepping stone models (Franks et al. 2004). Plant breeders exploit the variability existing in the trees by selecting desirable characteristics for use in domestication and genetic improvement (Katsvanga et al. 2007). According to Dawson et al. (2008), unless a wide genetic base within the species is maintained, trees are vulnerable to inbreeding depression ultimately reducing individual fitness and raises the chances of population and or species extinction.

Presently, there is scarcity of information on phenotypic and genetic structure of baobabs in southern Africa even though the species is extremely important socially and economically (Gruenwald and Galiza 2005; Akinnifesi et al. 2008b). Saka et al. (2008) reported significant differences in physico-chemical and nutritional contents between five provenances of baobab fruits in Malawi. However, the patterns and extent of fruit variation existing across populations occurring in varying silvicutural zones in Malawi remain unknown. Knowledge of variation in any species is prerequisite in agroforestry (Dawson et al. 2008) and any tree improvement programme (Wright 1976; Zobel and Talbert 1984). Successful domestication requires identification and use of good genetic germplasm. Furthermore, tree improvement and genetic conservation requires understanding of variation (Zobel and Tarbert 1984). The current study was undertaken to determine the pattern of fruit and seed variation occurring between and within

five baobab populations selected from different silvicultural zones in Malawi. The major questions addressed included the following: (i) What is the level of phenotypic variation existing between and within natural populations growing in different ecological zones based on climatic and edaphic factors? (ii) Could morphometric traits be used to delineate populations into distinct races (ecotypes)?

\section{Materials and Methods}

\section{Study site and fruit collection}

The study populations were selected as per the silvicultural zones ( $\mathrm{A}, \mathrm{Ba}, \mathrm{L}$ and $\mathrm{J}$ ) delineated by Hardcastle (1978) (Table 1, Fig. 1). In addition, Likoma Island population, apart from occurring 
Table 1 Physical description of sites (populations/provenances) and number of trees (families) sampled

\begin{tabular}{|c|c|c|c|c|c|c|c|}
\hline Population & $\begin{array}{l}\text { Population } \\
\text { Code }\end{array}$ & $\begin{array}{c}\text { Silviculture } \\
\text { Zone }\end{array}$ & $\begin{array}{l}\text { Average annual } \\
\text { Stress } \\
\text { Period (weeks)* }\end{array}$ & $\begin{array}{l}\text { Altitude } \\
\text { (m) }\end{array}$ & $\begin{array}{l}\text { Mean } \\
\text { annual } \\
\text { rainfall } \\
(\mathrm{mm})\end{array}$ & $\begin{array}{c}\text { Mean } \\
\text { annual } \\
\text { temperature } \\
\left({ }^{0} \mathrm{C}\right)\end{array}$ & Soil \\
\hline $\begin{array}{c}\text { Karonga } \\
(\mathrm{n}=7)\end{array}$ & K & $\mathrm{L}$ & $\begin{array}{c}\text { 7" Field } \\
\text { capacity: } 15 \\
\text { 12" Field } \\
\text { capacity": } 10 \\
\end{array}$ & $\begin{array}{l}475- \\
1000\end{array}$ & $>1600$ & $23-25$ & $\begin{array}{c}\text { Ferrisols } \\
\text { dominant ; } \\
\text { regosols }\end{array}$ \\
\hline $\begin{array}{l}\text { Salima } \\
(n=14)\end{array}$ & $\mathrm{S}$ & $\mathrm{Ba}$ & $\begin{array}{c}\text { 7" Field } \\
\text { capacity:28 } \\
\text { 12" Field } \\
\text { capacity: } 26\end{array}$ & $\begin{array}{l}200- \\
1200\end{array}$ & $710-850$ & $20-25$ & $\begin{array}{c}\text { Alluvial } \\
\text { calcimorphic } \\
\text { soils above } \\
\text { the vertisols }\end{array}$ \\
\hline $\begin{array}{c}\text { Mwanza } \\
(n=14)\end{array}$ & $\mathrm{M}$ & $\mathrm{J}$ & $\begin{array}{c}7 " \text { Field } \\
\text { capacity:16 } \\
12 " \text { Field } \\
\text { capacity: } 11\end{array}$ & $\begin{array}{l}900- \\
1500\end{array}$ & $\begin{array}{l}1200- \\
1600\end{array}$ & $19-21$ & $\begin{array}{c}\text { Sandy } \\
\text { ferrallitic }\end{array}$ \\
\hline $\begin{array}{c}\text { Chikwawa } \\
(\mathrm{n}=11)\end{array}$ & $\mathrm{C}$ & A & $\begin{array}{c}\text { 7" Field } \\
\text { capacity:35 } \\
\text { 12" Field } \\
\text { capacity: } 35\end{array}$ & $<200$ & $710-840$ & $>25$ & Vertisols \\
\hline $\begin{array}{l}\text { Likoma } \\
\text { Island } \\
(n=9)\end{array}$ & $\mathrm{L}$ & $\mathrm{L}$ & $\begin{array}{c}\text { 7" Field } \\
\text { capacity: } 15 \\
\text { 12" Field } \\
\text { capacity": } 10\end{array}$ & $\begin{array}{l}475- \\
1000\end{array}$ & $>1600$ & $23-25$ & $\begin{array}{c}\text { Ferrisols, } \\
\text { alluvial } \\
\text { calcimorphic, } \\
\text { regosols, } \\
\text { lithosols }\end{array}$ \\
\hline
\end{tabular}

Source: Hardcastle (1978)

* = Information on average annual stress calculations are reported by Hardcastle (1978)

in silviculture zone L, was included due to its geographical isolation. According to Hardcastle (1978), silviculture zone L has mean annual rainfall (MAR) $>1600 \mathrm{~mm}$ with predominantly weathered ferralitic soils. Silviculture zone Ba has MAR ranging between 710 to $850 \mathrm{~mm}$ and characterized by calcimorphic soils overlaying vertisols. Silviculture zone J has MAR ranging between 1200 to $1600 \mathrm{~mm}$ and characterized by ferrallitic soils whilst Silviculture zone A has MAR ranging between 710 to $840 \mathrm{~mm}$ with predominantly vertisols. Fruits were collected from Karonga, Likoma Island, Salima, Mwanza and Chikwawa populations at the peak of fruit season between April and May. Dry fruits were randomly collected from trees spaced at a minimum distance of $100 \mathrm{~m}$. Fruits were plucked from the tree and/or collected from the ground. A total 
of 55 families were characterized from the five populations, each consisting of different number of families ranging from 10 to 15 (Table 1).

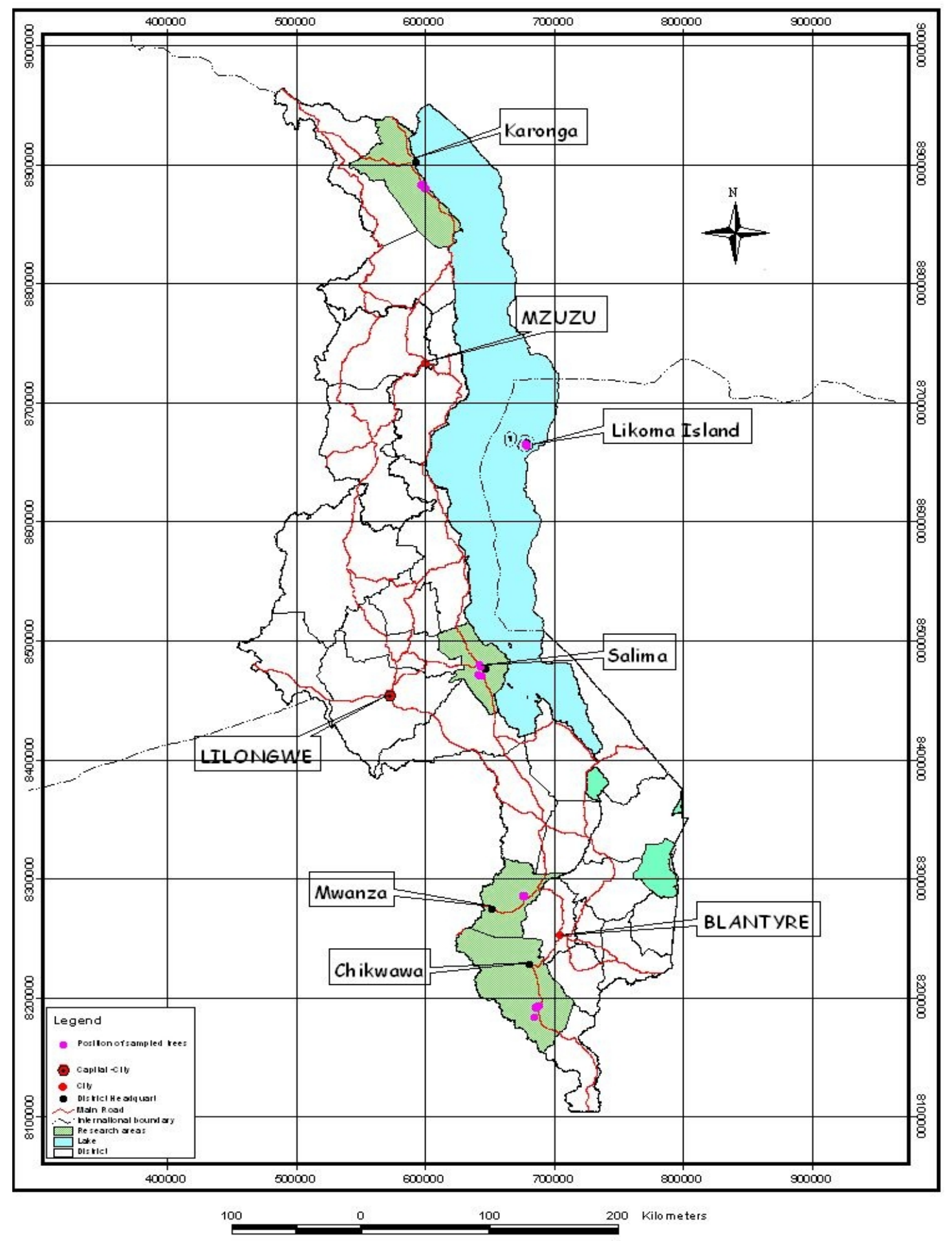

Fig. 1 Map of Malawi showing location of 5 sampled Adansonia digitata L populations 
Fruit assessment, seed characteristics and Data analysis

In total, fruits from 55 trees were characterized. From each tree 20 fruits were used to assess fresh fruit weight, fruit length and width. A sub-sample of ten fruits from each tree (family) were selected randomly to assess seed number, seed weight and pulp weight. A sub-sample of five seeds was randomly picked from each of ten fruits (50 seed per family) to measure individual seed weight, length and width. First fruit length $(\mathrm{cm})$ and width $(\mathrm{cm})$ were measured to the nearest $\mathrm{cm}$ and fresh fruits weighed to the nearest $\mathrm{g}$. After opening the fruit, the shell was removed from the shell content (pulp + seeds) and both fruit parts were weighed (to the nearest g). Fruit pulp and seeds were separated by dissolving the dry powdery pulp in water. After washing and drying, pulp weight was calculated by subtraction (Pulp+seed weight - seed weight). Individual seed weight was measured to the nearest hundredth of a $g$ whilst seed length and width to the nearest $\mathrm{mm}$.

The data on fruit and individual seed variation were analysed using nested analysis and means were separated by using the least significant differences (LSD) test.

\section{Results}

Fruit variation between provenances

Fruit weight differed significantly $(\mathrm{p} \leq 0.001)$ among the provenances (Table 2$)$, with the Mwanza provenance having the heaviest fruits $(162.9 \pm 3.25 \mathrm{~g})$ and Salima having the lowest weight

$(125.8 \pm 3.25 \mathrm{~g})$. Karonga and Chikwawa provenance were not different but Chikwawa was superior to Likoma Island and Salima. Coefficient of variation in fruit weight was $40 \%$. Fruit length was significantly $(\mathrm{p} \leq 0.001)$ different among provenances, with Mwanza having the longest fruits $(16.5 \pm 0.06 \mathrm{~cm})$ and Likoma Island having the shortest $(11.9 \pm 0.27 \mathrm{~cm})$. Salima was superior to both Chikwawa and Karonga. The coefficient of variation in fruit length was $18.9 \%$. Fruit width varied significantly $(\mathrm{p} \leq 0.001)$ among the provenances, with fruit width largest in Mwanza $(7.6 \pm 0.06 \mathrm{~cm})$ and Salima having the smallest $(6.8 \pm 0.06 \mathrm{~cm})$. Mwanza, 
Karonga and Likoma Island were not different while Chikwawa was superior to Salima. The coefficient of variation in fruit width was $14.1 \%$. Number of seed varied significantly $(\mathrm{p} \leq 0.001)$

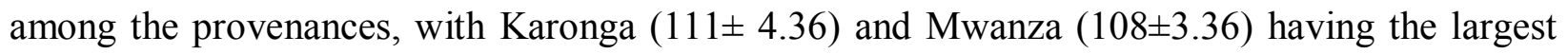
number of seed followed by Likoma $(99 \pm 4.18)$ and Chikwawa $(91 \pm 3.74)$ with Salima having the least $(86 \pm 3.36)$. The coefficient of variation in number of seed was $42 \%$. Seed weight varied significantly $(\mathrm{p} \leq 0.001)$ among the provenances, with Mwanza having heaviest seed weight $(66 \pm$ $2.01 \mathrm{~g})$ and Likoma Island having the lowest $(38.6 \pm 2.5 \mathrm{~g})$. Chikwawa and Karonga were not different while Salima was superior to Likoma Island. The coefficient of variation in seed weight was $39.2 \%$. Seed weight constituted on average 39\% of whole fruit weight. Pulp weight was significantly $(\mathrm{p} \leq 0.001)$ different among provenances, with Chikwawa having the heaviest pulp weight $(41.4 \pm 1.33 \mathrm{~g})$ and Salima having the lowest $(28.7 \pm 1.33 \mathrm{~g})$. Mwanza and Chikwawa were not different but superior to Salima. The coefficient of variation in pulp weight was $45.1 \%$. Pulp weight constituted on average $20 \%$ of whole fruit weight.

Table 1 Variation in fruit traits among five provenances of Adansonia digitata $\mathrm{L}$

\begin{tabular}{|c|c|c|c|c|c|c|}
\hline Provenance & $\begin{array}{l}\text { Fruit weight } \\
\text { (g) }\end{array}$ & $\begin{array}{l}\text { Fruit length } \\
(\mathrm{cm})\end{array}$ & $\begin{array}{l}\text { Fruit width } \\
(\mathrm{cm})\end{array}$ & $\begin{array}{l}\text { Number of } \\
\text { Seed }\end{array}$ & $\begin{array}{l}\text { Seed weight } \\
\text { (g) }\end{array}$ & $\begin{array}{l}\text { Pulp weight } \\
\text { (g) }\end{array}$ \\
\hline Mwanza & $162.9 \pm 3.25 a$ & $16.5 \pm 0.16 \mathrm{a}$ & $7.6 \pm 0.06 a$ & $108 \pm 3.36 \mathrm{a}$ & $66.0 \pm 2.01 \mathrm{a}$ & $41.4 \pm 1.33 a$ \\
\hline Chikwawa & $142.9 \pm 3.31 b$ & $13.8 \pm 0.16 \mathrm{c}$ & $7.1 \pm 0.06 b$ & $91 \pm 3.74 b$ & $58.7 \pm 2.24 b$ & $41.5 \pm 1.48 \mathrm{a}$ \\
\hline Karonga & $136.8 \pm 4.32 b c$ & $13.4 \pm 0.30 \mathrm{c}$ & $7.5 \pm 0.08 \mathrm{a}$ & $111 \pm 4.36 \mathrm{a}$ & $58.5 \pm 2.61 b$ & $34.5 \pm 1.73 b$ \\
\hline Likoma Island & $128.8 \pm 4.00 \mathrm{c}$ & $11.9 \pm 0.27 \mathrm{~d}$ & $7.5 \pm 0.07 a$ & $99 \pm 4.18 b$ & $38.6 \pm 2.50 \mathrm{~d}$ & $34.7 \pm 1.66 b$ \\
\hline Salima & $125.8 \pm 3.25 \mathrm{c}$ & $14.4 \pm 0.16 b$ & $6.8 \pm 0.06 c$ & $86 \pm 3.36 c$ & $49.5 \pm 2.01 \mathrm{c}$ & $28.7 \pm 1.33 \mathrm{c}$ \\
\hline$\%$ Fruit wt & & & & & 39 & 20 \\
\hline LSD & 10.62 & 0.51 & 0.19 & 10.81 & 6.47 & 4.29 \\
\hline CV (\%) & 40 & 18.9 & 14.1 & 42 & 44.7 & 45.1 \\
\hline
\end{tabular}


Within all provenances, variation in mean fruit weight among trees was significantly different ( $\mathrm{P}$ $\leq 0.001$ ) (Fig. 2). Across all the provenances, mean fruit weight ranged from $61.2 \pm 12.6 \mathrm{~g}$ in one tree in Likoma Island (L5) to $256.1 \pm 12.6 \mathrm{~g}$ in a tree in Chikwawa (C15). Seed weight variation was significantly different $(\mathrm{P} \leq 0.001)$ (Fig. 3) within all the provenances. Across all the provenances, seed weight ranged from $6.9 \pm 7.8 \mathrm{~g}$ in one tree in Likoma Island (L5) to 115.4 $\pm 7.8 \mathrm{~g}$ in a tree in Chikwawa (C10). Pulp weight variation was significantly different $(\mathrm{P} \leq 0.001)$ (Fig. 4). Across all the provenances, pulp weight ranged from $15.4 \pm 5.2 \mathrm{~g}$ in one tree in Likoma Island (L5) to $69.1 \pm 5.2 \mathrm{~g}$ in a tree in Chikwawa (C10).

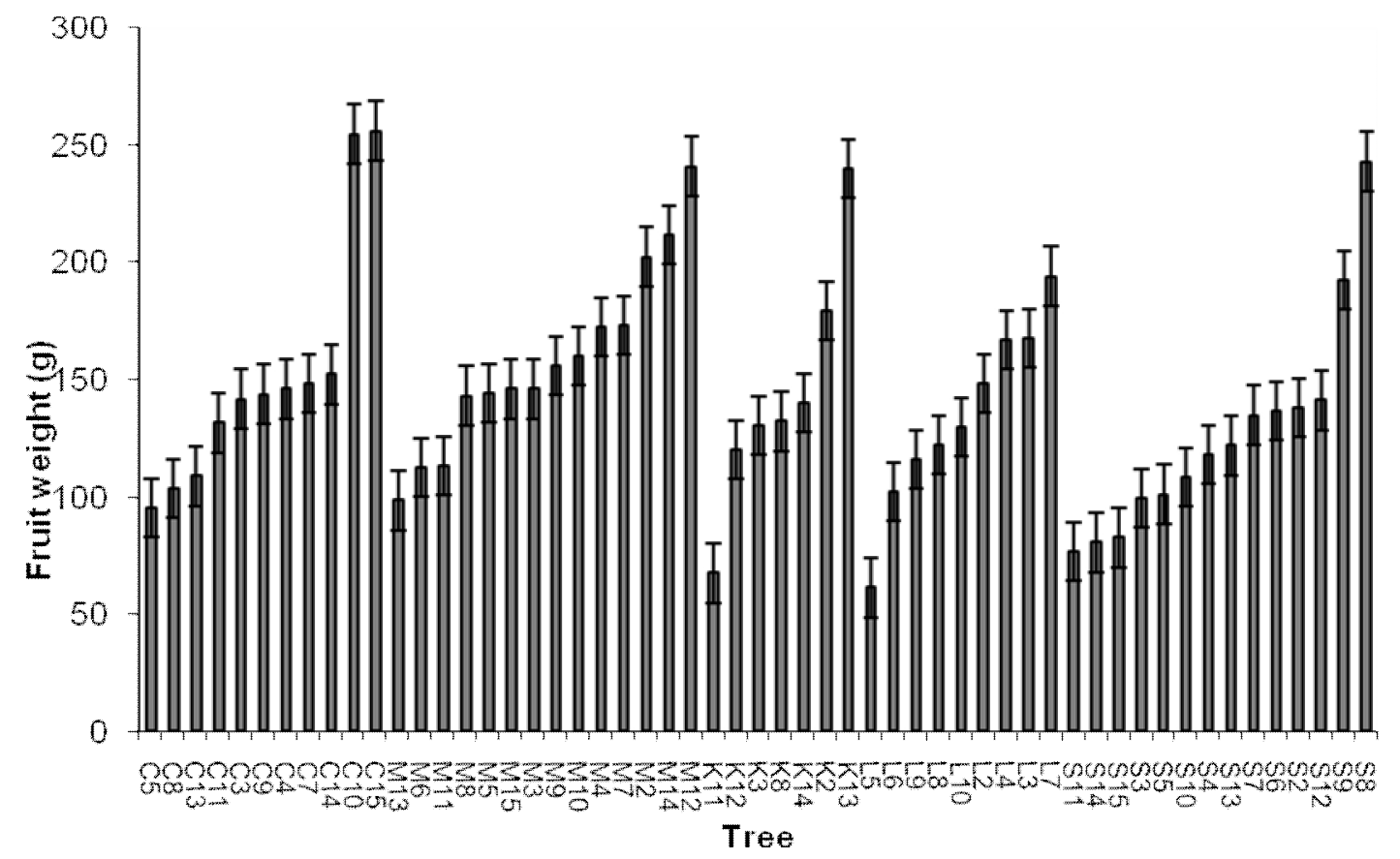

Fig. 1 Fruit weight variation within five provenances of Adansonia digitata $(\mathrm{C}=$ Chikwawa, $\mathrm{M}=$ Mwanza, $\mathrm{S}=$ Salima, $\mathrm{L}=$ Likoma Island and $\mathrm{K}=$ Karonga; label of individual trees range from 1 to 15 ) 


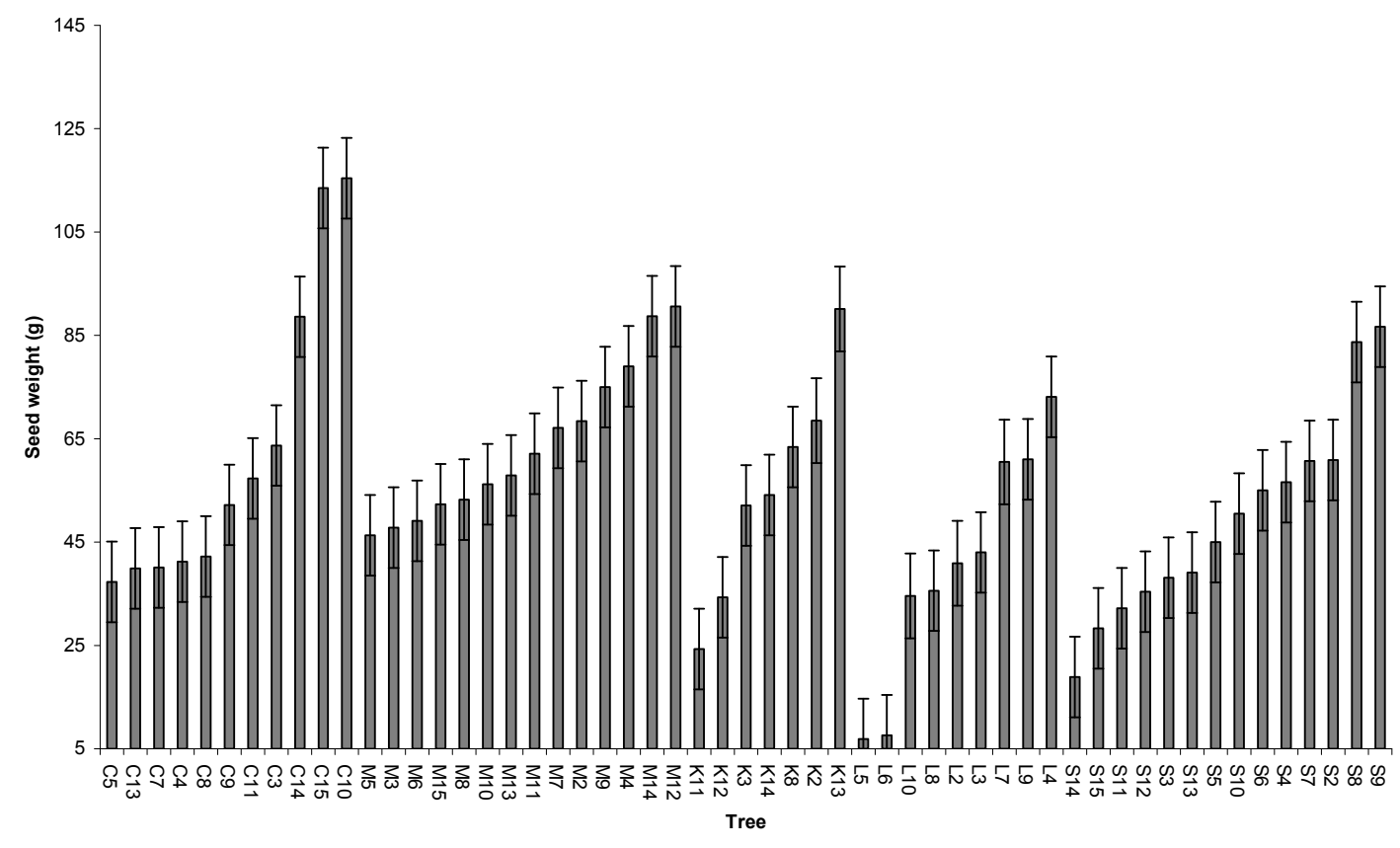

Fig. 2 Seed weight variation within five provenances of Adansonia digitata L

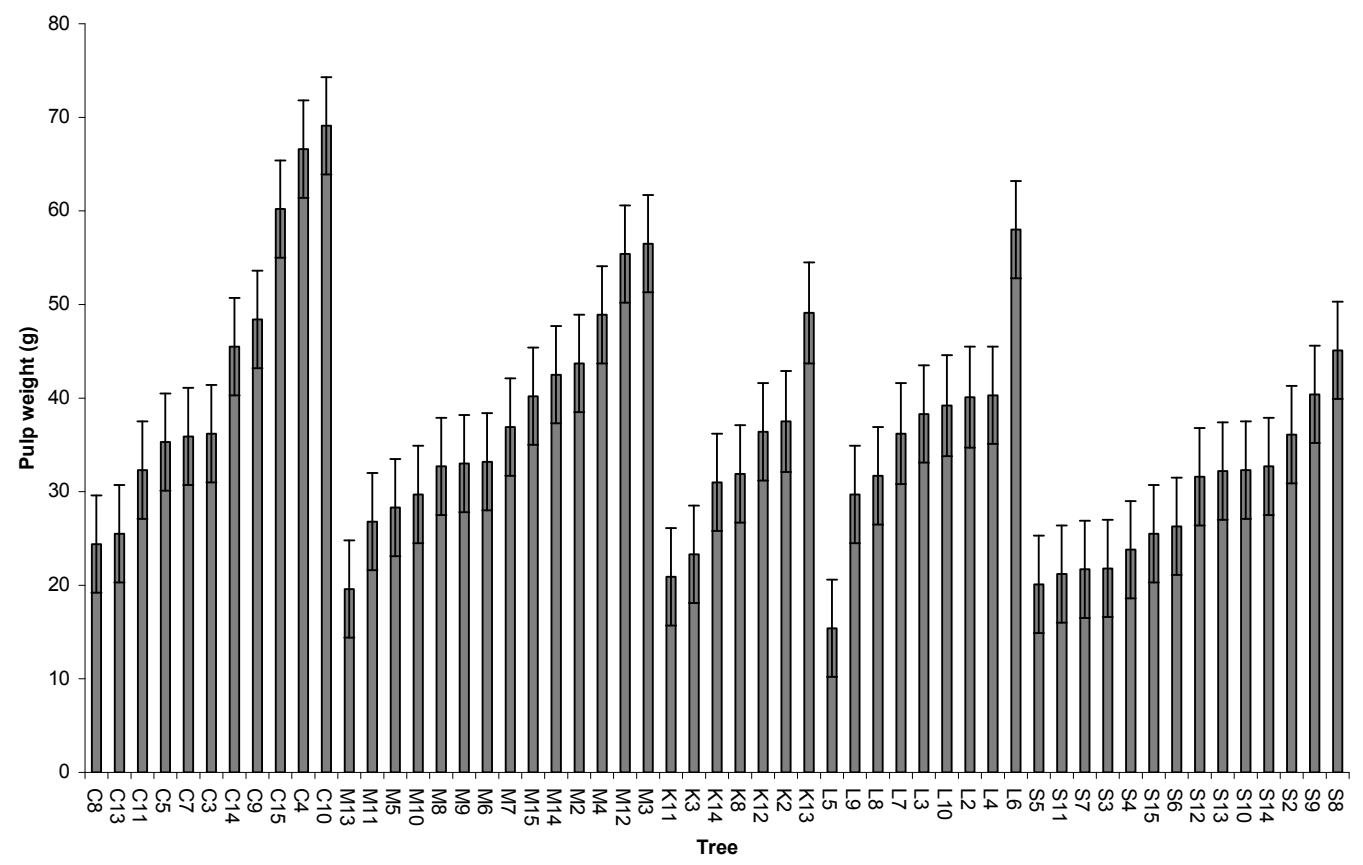

Fig. 3 Pulp weight variation within five provenances of Adansonia digitata L 


\section{Single seed variation between provenances}

Single seed weight was significantly different $(\mathrm{P} \leq 0.001)$ among provenances, with Chikwawa having the heaviest single seed weight $(0.576 \pm 0.003 \mathrm{~g})$ and Likoma Island having the lowest weight $(0.367 \pm 0.003 \mathrm{~g})$. Mwanza and Salima were not different. Karonga was superior to Likoma Island. The coefficient of variation in single seed weight was $13.9 \%$. Single seed length was significantly different $(\mathrm{P} \leq 0.001)$ among provenances, with Chikwawa having the longest seed length $(12.5 \pm 0.03 \mathrm{~mm})$ and Likoma Island having the shortest $(10.9 \pm 0.04 \mathrm{~mm})$. Mwanza, Karonga and Salima were not different. The coefficient of variation in seed length was $6.1 \%$. Seed width was significantly different $(\mathrm{P} \leq 0.001)$ among the provenances, with seed width largest in Chikwawa $(10.0 \pm 0.02 \mathrm{~mm})$ and Likoma Island having the shortest $(8.9 \pm 0.03 \mathrm{~mm})$. Mwanza was superior to Karonga and Salima. The coefficient of variation in seed width was $6.5 \%$.

Table 2 Variation in single seed parameters among five provenances of Adansonia digitata $\mathbf{L}$

\begin{tabular}{lllc}
\hline Provenance & Seed weight $(\mathrm{g})$ & Seed length $(\mathrm{mm})$ & Seed width $(\mathrm{mm})$ \\
\hline Mwanza & $0.509 \pm 0.003 \mathrm{~b}$ & $11.8 \pm 0.03 \mathrm{~b}$ & $9.5 \pm 0.02 \mathrm{~b}$ \\
Chikwawa & $0.576 \pm 0.003 \mathrm{a}$ & $12.5 \pm 0.03 \mathrm{a}$ & $10.0 \pm 0.02 \mathrm{a}$ \\
Karonga & $0.476 \pm 0.004 \mathrm{c}$ & $11.8 \pm 0.03 \mathrm{~b}$ & $9.4 \pm 0.03 \mathrm{c}$ \\
Likoma Island & $0.367 \pm 0.003 \mathrm{~d}$ & $10.9 \pm 0.04 \mathrm{c}$ & $8.9 \pm 0.03 \mathrm{~d}$ \\
Salima & $0.502 \pm 0.003 \mathrm{~b}$ & $11.7 \pm 0.03 \mathrm{~b}$ & $9.4 \pm 0.02 \mathrm{c}$ \\
LSD & 0.009 & 0.091 & 0.077 \\
CV (\%) & 13.9 & 6.1 & 6.5 \\
\hline
\end{tabular}

Mean are followed by the standard error of the mean,

Mean followed by the same letter are not significantly different at $(\mathrm{P} \leq 0.001)$

\section{Discussion}

Fruit variation between and within provenances

In order to fulfill the goal of meeting the demands of subsistence farmers and product markets, the knowledge of intraspecific diversity of the baobab trees is fundamental. Current results help to fill the gap of information for baobab phenotypic diversity for fruit characteristics and 
individual seed traits for use in the domestication and tree improvement process. The present results have revealed substantial variation in fruit traits (fruit weight, length and width, seed number and weight and pulp weight between (Table 2) and within (Fig. 2, 3, 4) the provenances. Considering the best and lowest mean, between provenance variation was of high magnitude: fruit weight $119 \%$, fruit length $37 \%$, fruit width $12 \%$, number of seeds $26 \%$, quantity of seed $33 \%$ and pulp weight $44 \%$. Extremely high variation existed at family level for example $318 \%$ for fruit weight, $1572 \%$ seed weight and $476 \%$ pulp weight. The findings are important because they suggest the potential of achieving high genetic gains through classical tree breeding and through vegetative propagation. The results support the assertion that use of clones in fruit trees might increase productivity rapidly (Akinnifesi et al. 2008a). The presence of high coefficient of variation $(\mathrm{CV}=40-45 \%)$ indicates the presence of high environmental impact where as low values ( $\mathrm{CV}=14-19)$ could be an indication of strong genetic control (Kimmins 1987). In the case of our study, fruit weight, seed weight and pulp weight had high environmental influence. Most qualitative traits such as fruit length and width are strongly inherited such that $60 \%$ of the progeny might be similar to their parents (Akinnifesi et al. 2008b). Therefore, these qualitative traits are easily improved through clonal selection. On the other hand quantitative traits such as fruit weight, seed number and weight and pulp weight should be influenced partly by additive gene effects, environment and interaction of genotype x environment (Zobel and Tarbert 1984). Thus, quantitative traits require classical breeding to achieve high genetic gains (Zobel and Tarbert 1984). The diversity of fruit sizes found in this study has unveiled high polymorphism existing in populations of baobabs in the country. Nearly all the forms of fruits described by Wickens (1982) such as globose, bluntly ovoid, sharply ovoid, large ovoid, shallow sulcate and oblong-cylindrical (Fig. 5) exist within the nation. This implies rich diversity that does not require an infusion of external genetic material for immediate domestication and genetic improvement programmes. The patterns of fruit sizes presently found can not be used to specifically classify populations as ecotypes due to overlapping in multiple comparison tests. Generally all the populations possess fruit sizes that are of economic value and can be used for domestication purposes. However, further research is required to assess the frequencies of different fruit types between and within the sites. Our results indicate viability of increasing baobab fruit productivity through clonal forestry as advocated by ICRAF (Akinnifesi et al. 
2008a). However, it should be supported by research on genotype $x$ environmental interaction (clonal plasticity) especially for quantitative traits that have large environmental influence.

The largest component of fruit weight (39\%) constituted seed weight. Seed has many economical attributes such as oil for cooking and cosmetic industries (Gruenwald and Galizia 2005; Kalinganire et al. 2008; Teklehaimanot et al. 2008; Venter et al. 2011). Presently, the product is not fully utilized in southern Africa, usually considered as a waste by product of juice making. Once promoted, seed weight could be improved through selection that may significantly uplift the life of many rural masses.

In general, sale of fruits is based on size (weight, length, width) (Franzel et al. 2008); with bigger fruits fetching higher prices. Tree breeding may target trees with bigger fruits. However, there seems to be no relationship between taste and size of the fruit which complicates the choice of selection criteria. Ramadhani and Schmidt (2008) reported that consumer preference and willingness to buy fruits is not always dictated by fruit size but taste as well. For instance, small tasty fruits were considered good quality fruit which may apply to baobabs fruits as well. Thus, small tasty fruits might be considered for tree breeding selection as well. It has been reported by Katsvanga et al. (2007) that high fruit diversity attributes among sites could be attributed to climatic, edaphic, genetic and cultural factors. In the case of our sampling sites (Table 1), there were huge differences in environmental factors which may be linked to differences in fruit weight related parameters observed. Domestication process involves moving genotypes from one site to another. Presently, it is not known how genotypes would respond once planted in an exotic habitat. Will the fruit quality (shape, size, seed number, seed weight, pulp colour, nutrition and weight) be consistent when seed is moved from one ecological zone to another? In this case, provenance and family evaluation are prerequisite for successful large domestication programmes. Some of the questions to answer in an evaluation programme will be whether there are relationships between altitude, latitude, rainfall, temperature, relative humidity, stress period and edaphic factors on the fruit attributes. Fruit attributes are also influence by tree management (Katsvanga et al. 2007) such as spacing, pruning, fertilization, irrigation and mulching. Currently it is unknown how baobabs would respond to different silvicultural practices. Further research is required since Zobel and Tarbert 1984 are of the view that to optimize tree productivity a 
combination of choice of parentage and silvicultural management should be observed. However, Akinnifesi et al. (2008a) reported varying responses to cultural management for miombo species: Vangueria infausta performed better with a combination of light dry-season irrigation and manuring whilst combining use of manure, fertilizer and irrigation did not improve yield in Uapaka kirkiana and Sclerocarya birrea. In Mali, baobab leaf production was extended through irrigation especially for black morphotypes and it was presumed applicable to fruit production too (Kalinganire et al. 2008).

The variation in fruit characteristics for individual trees (Fig.2, 3, 4) show clear trends that the higher the fruit weight the higher the seed weight. The results are supported by Mkonda et al. (2003) who reported strong relationship between seed weight and fruit weight in Strychnos cocculoides because the sink strength of fruits depends on the numbers and sizes of the seed they contain. In addition, seeds constitute the priority sink as they have bigger share of substrates than the other fruit tree parts. This could also explain the consistently low pulp weight in most fruits as compared with seed weight. There were, however, few exceptions where some trees had almost the same level of seed weight and pulp weight. Currently, pulp weight is the most important economic product (Gruenwald and Galiza 2005). Therefore, more economic weighting should be put on this trait in selection index. The results however seem to show that indirect selection of pulp weight based on fruit weight may end up with large error margins because some fruits with high fruit weight are not necessarily having significantly different fruit pulp than relatively smaller fruits as shown by different ranking of trees within provenances in Fig.3 and Fig.4 in relation to Fig.2. Additionally, pulp weight is influenced by environmental factors largely by the amount of rainfall (Katsvanga et al. 2007). This implies that selection of plus trees to improve pulp production should be done following several seasons of data collection of pulp production.

Our results compare favourably with several published literature on baobab phenotypic variations: (Barwick 2004; Carr 1958; De Smedt, et al. 2011; FAO, 1982; Gebauer et al. 2002; Gruenwald and Galiza 2005; Nour et al. 1980). Gruenwald and Galiza (2005) reported that the percentage of fruit pulp varies according to the origin. In southern Africa, fruit pulp constitutes $16.5 \%$ of the fruit weight and seed weight $38 \%$ whilst in Senegal fruit pulp is about $12 \%$. 
Gebauer et al. (2002) reported variation in fruit length of 20 to $30 \mathrm{~cm}$ and width diameter up to $10 \mathrm{~cm}$. Barwick (2004) reported fruit length of up to $30 \mathrm{~cm}$. Carr (1958) reported range in mean fruit weight of $59.5 \mathrm{~g}$ to $88 \mathrm{~g}$ in one study and $173.2 \mathrm{~g}$ to $252 \mathrm{~g}$ in another. Carr (1958) also reported mean percentage seed in whole fruit of $34.9 \%$ and $14.3 \%$ for pulp weight. Green (1932) reported composition of seed weight of $40 \%$ and 15\% for pulp. FAO (1982) have also reported baobab fruit size of up to $35 \mathrm{~cm}$ length by 8 to $15 \mathrm{~cm}$ width. De Smedt et al. (2011) have reported mean pulp yield per fruit of $45 \pm 1 \mathrm{~g}$ and seed production of $71 \pm 2 \mathrm{~g}$. Our results on pulp weight was higher because it included moisture content of fresh pulp (sun dried) which ranges from 10 to $12 \%$ compared with oven dried values (Gruenwald and Galiza 2005).

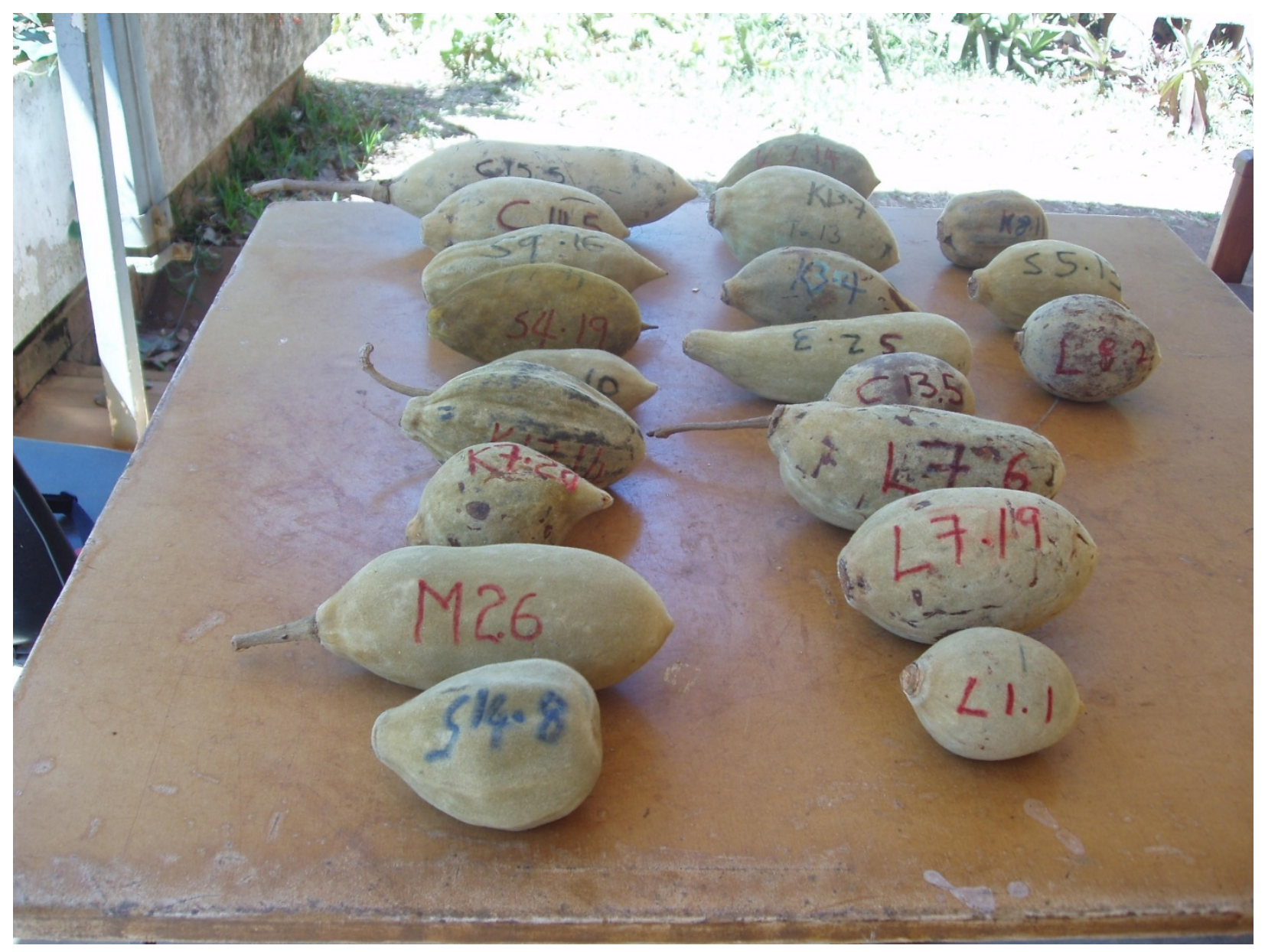

Fig. 4 Fruit variation between and within five populations of Adansonia digitata L in Malawi 
Most literature in baobab has not reported variation in individual seed traits. However, the range of seed traits found in this study is similar to values reported by Owen (1999) of seed size measuring $5 \mathrm{~mm}$ by $10 \mathrm{~mm}$ and weighing on average $0.65 \mathrm{~g}$. Msanga (1998) reported seed dimensions of $12 \mathrm{~mm}$ in length and $8 \mathrm{~mm}$ broad. The differences in reported results are showing importance of studying variation at regional scale. Low coefficient of variation (6.1-13.9\%) between populations in seed trait (Table 3) might indicate that the traits are highly genetically controlled (Kimmins 1987). Seed characteristics may also strongly depict species adaptability (Chapman and Reiss 2000). Multiple comparison tests clustered the populations differently depending on seed trait (see Table 3). Likoma Island population is consistently classified differently from the other four mainland populations. The contributing factor could be difference in climate especially higher available moisture and short period of moisture stress since it has a maritime climate - influenced by surrounding Lake Malawi. Not surprising, due to low water stress, the seed is the lightest and smallest which may imply that trees do not need to reserve much substrates for the seedlings to survive in the environment (Katsvanga et al. 2007). Similarly, rainfall pattern of Karonga and Salima populations are partly influenced by Lake Malawi; and as such their seed characteristics are intermediate. The other two populations, Chikwawa and Mwanza, are both in land populations but lie in different topographic regions influenced by different climatic regimes (see Table 1). Chikwawa has an extremely harsh climate such as high temperature and long moisture stress. Thus, the seeds are heavy and large due to stored reserves (substrates) presumably adequate for the seedlings to survive well; unlike Mwanza where the population is in a wetter place but still experiences relatively prolonged stress period. This could explain why the population was ranked second for the heaviest and largest seed. The differentiation in seed traits is suggesting that populations with time may have evolved differently due to different ecological conditions (Kimmins 1987). These results are similar to the findings on Pterocurpus angolensis (Munthali 1999) where it was reported that rainfall strongly influenced seed size. In this case, populations receiving heavy rainfall had lightest seed while those from low rainfall areas had heaviest seed. These results are supported by earlier reports on miombo tree species (Munyanziza 1996) which are said to react to stress by developing large seed with large cotyledons that feed developing seedlings. The same 
phenomenon is suggested in this study: Chikwawa and Mwanza provenances could have heavy seed because they experience severe water stress as compared with the other populations. Thus, it can be argued that rainfall regime may have partitioned baobab populations into ecotypes in Malawi. Overlapping of the provenances could be due to gradual differentiation or introgression as a result of continuous variation in some subpopulations (Frank et al. 2004). For example most of the populations occur in the Lake Shore areas without many barriers. Current results also mirror findings of Mwase et al. (2006) who found variation in seed weight in Uapaka kirkiana provenances and attributed divergence in seed traits due to differences in water availability with changes in elevation. Ngulube et al. (1996) attributed variation in seed size in Uapaka kirkiana due to genetic and environmental effects too. Present results of seed weight may imply that the trait could be used to predict genetic structuring between populations and distinguish the populations from different ecological zones.

\section{Conclusion}

Large between and within provenance phenotypic diversity found in this study indicates great potential for improving fruit quality. The fruit variation between provenances ranging from $12 \%$ to $119 \%$ and between tree to tree variation $318 \%$ to $1572 \%$ is wide enough for domestication initiatives and further demonstrate substantial genetic gains that could be achieved through selection and breeding. The variation found can be quickly harnessed in tree improvement through vegetative propagation that can also accelerate fruit precosity from more than ten years to four years (Kalinganire et al. 2008). The breeding strategy may also use sexual procedure to increase genetic diversity. Combined selection of provenance and tree to tree (family) variation could be used to attain high genetic gains. However since baobab is a fruit tree, sexual reproduction may result in gene segregation which will eventually affect fruit quality. Research should be initiated to understand inheritance of fruit traits and information generated will be used for designing tree breeding strategies. Following high diversity in all provenances, all populations can be used for selection depending on the trait being selected for. Overlapping in clustering of populations in fruit characteristics does not provide an easy way of delineating

populations as distinct gene pools. However, Mwanza and Salima were consistently different from other populations probably showing that they are unique ecotypes. The other three 
populations were generally intermediate which may imply that they are genetically similar. However, fruit characteristics are greatly affected by environmental factors, cultural factors and additive gene effects (Kasvanga et al. 2007). Further studies are required to understand plasticity of traits of economic importance such as fruit pulp and nutritional aspects. In addition, horticultural studies should be done to test the effect of cultivation on fruit attributes especially following clonal selection. It has been argued that during the development of germplasm networks, proper consideration should be given to geographic scale because significant maladaptation and/or out-breeding depression are possible if germplasm exchange occurs over too large a geographic area (Dawson et al. 2008). In the present study, individual seed weight also seemed to strongly suggest populations of Chikwawa, Karonga and Likoma Island are unique ecotypes while Mwanza and Salima are similar. The question is whether the seed for these populations can be adapted (distributed and planted) in all the silvicultural zones. The present study has demonstrated importance of studying variation in fruit trees. Baobab occurs widely in southern Africa, but it is still poorly researched in population genetics. It will be important to extensively investigate the spatial genetic structuring in the species in the region so that the information could be used in tree domestication, conservation, management and improvement. In addition, further molecular studies should be done to assess genetic diversity at large scale (regional) and fine scale (within countries) to complement on the current study. So far the results are showing all provenances have substantial fruit diversity that may be put to use in domestication and tree improvement strategies.

\section{Acknowledgements}

The first author would like to acknowledge funding for the study from Universities of Mzuzu and Stellenbosch and University of Pretoria for facilitation during write up of the research.

We also thank all the technical personnel who were involved in fruit collection, processing and measurements. 


\section{References}

Akinnifesi FK, Ajayi OC, Sileshi G, Matakala P, Kwesiga FR, Ham C, Kadzere I, Mhango J, Mng'omba SA, Chilanga T, Mkonda A (2008a) Creating opportunities for domestication and commercializing Miombo Indigenous Fruit Trees in Southern Africa. In: Akinnifesi, FK, Leaky RRB, Ajayi OC, Silesh G, Tchoundjeu Z, Matakala P, Kwesiga FR (eds.) Indigenous Fruit Trees in the Tropics Domestication, Utilization and Commercialization. Columns Design Ltd, Reading, UK

Akinnifesi FK, Sileshi G, Ajayi OC, Chirwa PW, Kwesiga FR, Harawa R (2008b) Contribution of Agroforestry Research and Development to Livelihood of Smallholder Farmers in Southern Africa:2.Fruit, Medicinal, Fuelwood and Fodder Tree Systems. Agricultural Journal 3(1): 76-88 Barwick M (2004) Tropical and Subtropical Trees: A worldwide Ecyclopaedic Guide, Thames and Hudson, London, UK

Bizoux J, Mahy G (2007) Within -Population Genetic Structure and Clonal Diversity of a Threatened Endemic Metallophyte, Viola calaminaria (Violaceae). American Journal of Botany 94 (5): 887-895

Buiteveld J, vendramin GG, Leonardi S, Kamer K, Geburek T (2007) Genetic diversity and differentian in European beech (Fagus sylvatica L.) stands varying in management history. Forest Ecology and Management 247:98-106

Carmora A, Casas A (2005) Management, phenotypic patterns and domestication of Polaskia chichipe (Cactaceae) in the Tehua Can Valley, Central Mexico. Journal of Arid Environments 60: $115-132$

Chapman JL, Reiss MJ (2000) Ecology Principals and Applications (2 ${ }^{\text {nd }}$ Edition). Cambridge University Press, UK 
Chirwa M, Chithira V, Kayambazinthu D, Dohse C (2006) Distribution and Population Structures of Adansonia digitata in Some Parts of Ntcheu, Dedza and Mangochi Districts, Malawi. FRIM Report No. 06002

Chung M, Nason J, Chung M, Kim K, Park C, Sun B, Pak J (2002) Landscape-Level Spatial Genetic Structure in Quercus acutissima (Fagaceae). American Journal of Botany 89 (8): 12291236

De Smedt S, Alaerts K, Kouyate AM, Van Damme P, Potters G, Samson R (2011) Phenotypic variation of baobab (Adansonia digitata L.) fruit traits in Mali. Agroforest Syst 82:87-97. DOI $10.1007 / \mathrm{s} 10457-010-9357-0$

Donahue JK, Upton JL (1996) Geographic variation in leaf, cone and seed morphology of Pinus greggii in native forests. Forest Ecology and Management 82: 145-147

Environmental affairs Department (2006) National Biodiversity Strategy and Action Plan. Ministry of Energy, Mines and Natural Resources. The Government Printer, Lilongwe, Malawi FAO (1982) Fruit bearing Forest trees. FAO Forest Paper, Vol 34

Franks SJ, Richards CL, Gonzales J, Cousins JE, Hamrick (2004) Multi-scale genetic analysis of Uniola paniculata (Poaceae): A coastal species with a linear, fragmented distribution. American Journal of Botany 91 (9): 1345-1351

Franzel S, Akinnifesi FK, Ham C (2008) Setting Priorities among Indigenous Fruit Tree Species in Africa: Examples from Southern, Eastern and Western African Regions. In: Akinnifesi, FK, Leaky RRB, Ajayi OC, Silesh G, Tchoundjeu Z, Matakala P, Kwesiga FR (eds.) Indigenous Fruit Trees in the Tropics Domestication, Utilization and Commercialization. Columns Design Ltd, Reading, UK 
Gebauer J, El-Siddig K, Ebert G (2002) Baobab (Adansonia digitata L.): a Review on a Multipurpose Tree with Promising Future in the Sudan. Gartenbauwissenschaft, 67(4).S. 155160

Green RA (1932) Composition of the pulp and seeds of Adansonia digitata. Botanical Gazette, vol.94(1): $215-220$

Gruenwald J, Galizia MD (2005) Market Brief in the European Union for selected natural ingredients derived from native species. Adansonia Digitata L. Baobab. The United Nations Conference on Trade and Development (UNCTAD). Bio Trade Initiative/BioTrade Facilitation Programme (BTFP)

Hardcastle PD (1978) A preliminary silvicultural classification of Malawi. Forestry Research Institute of Malawi. Forestry Research Record No. 57

ICUC (2002) Fruits for the Future, Baobab. International Center for Underutilized crops. Factsheet No.4, March 2002, Southampton, UK

Kalinganire A, Weber JC, Uwamariya A and Kone B (2008) Improving Rural Livelihoods through Domestication of Indigenous Fruit Trees in the Parklands of the Sahel. In: Akinnifesi FK, Leaky RRB, Ajayi OC, Silesh G, Tchoundjeu Z, Matakala P, Kwesiga FR (eds.) Indigenous Fruit Trees in the Tropics Domestication, Utilization and Commercialization. Columns Design Ltd, Reading, UK

Katsvanga CAT, Jim L, Gwenzi D, Muhoni L, Masuka P, Moyo M (2007) Characterisation of community identified Uapaka kirkiana phenotypes for domestication. Journal of Sustainable Development in Africa Volume 9 No.4:356-366

Mkonda A, Lungu S, Maghembe JA, Mafongoya PL (2003) Fruit-and seed-germination characteristics of Strychnos cocculoides an indigenous fruit tree from natural populations in Zambia. Agroforestry Systems 58: 25-31 
Moiselet D (1998) The Baobab Tree. http://www.senegal-online.com/anglais/pares-fauneflore/baobab.htm. Site visited on 8/28/03

Msanga, H.P., 1998. Seed germination of indigenous trees in Tanzania: including notes on seed processing, storage and plant uses. Canadian Forest Service, Edmontort, Alberta

Munthali CRY (1999) Seed and seedling variation of Pterocarpus angolensis DC from selected natural populations of Malawi. Dissertation, University of Stellenbosch

Munyanziza E (1996) Miombo trees: Ecology strategies, silviculture and management. Ambio $25,7: 454-458$

Mwase WF, Bjornstad A, Ntupanyama YM, Kwapata MB, Bokosi JM (2006) Phenotypic variation in fruit, seed and seedling traits of nine Uapaka kirkiana provenances found in Malawi. Southern African Forestry Journal, No.208, 15-21

Nour A, Magboul, BI, Kheir NH (1980) Chemical composition of baobab fruit (Adansonia digitata L.). Trop. Sci. 1980, 22(4): 383-388

Owen M (1999) Desk Study: Baobab fruit and oil. SAFIRE, June 1999

Ramadhani T, Schmidt E (2008) Marketing of Indigenous Fruits in Southern Africa. In: Akinnifesi, FK, Leaky RRB, Ajayi OC, Silesh G, Tchoundjeu Z, Matakala P, Kwesiga FR (eds.) Indigenous Fruit Trees in the Tropics Domestication, Utilization and Commercialization. Columns Design Ltd, Reading, UK

Sacande M, Ronne C, Sanon M, Joker D (2006) Adansonia digitata L. SEED LEAFLET. No. 109 January 2006, Millennium Seed Bank Project, Kew, UK 
Saka JDK, Kadzere I, Ndabikunze BK, Akinnifesi FK, Tiisekwa BPM (2008) Product Development: Nutritional Value, Processing and Utilization of Indigenous fruits from the Miombo Ecosystem. In: Akinnifesi, FK, Leaky RRB, Ajayi OC, Silesh G, Tchoundjeu Z, Matakala P, Kwesiga FR (eds.) Indigenous Fruit Trees in the Tropics Domestication, Utilization and Commercialization. Columns Design Ltd, Reading, UK

Sidibe M, Williams JT (2002) Baobab, Adansonia digitata. International Centre for Underutilised crops, Southampton, UK

Teklehaimanot Z (2008) The Role of Indigenous Fruit Trees in Sustainable Dryland Agriculture in Eastern Africa. In: Akinnifesi, FK, Leaky RRB, Ajayi OC, Silesh G, Tchoundjeu Z, Matakala P, Kwesiga FR (eds.) Indigenous Fruit Trees in the Tropics Domestication, Utilization and Commercialization. Columns Design Ltd, Reading, UK

Venter SM, Witkowski ETF (2011) Baobab (Adansonia digitata L.) fruit production in communal and conservation Land-use types in southern Africa. Forest Ecology and Management 261:630-639

Zobel B, Talbert J (1984) Applied Forest Tree Improvement. John Wily and Sons, Inc. New York

Wright JW (1976) Introduction to Forest Genetics. ACADEMIC PRESS, New York 